\title{
内装部材のプレカット化のための 3 次元レーザースキャナーを用いた計測と 生産設計の手法に関する研究 \\ STUDY ON MEASURING OF REINFORCED-CONCRETE STRUCTURE \\ BY 3D LASER SCANNER AND MAKING DESIGN OF \\ PRE-CUT INTERIOR FINISHING COMPONENTS \\ WITH POLYGON MODEL
}

石田航星 ${ }^{* 1}$, 嘉納成男 ${ }^{* 2}$, 五十嵐 健 ${ }^{* 3}$, 藤井裕彦*4

大 澤雄 司*4, 酒本 晋太郎*5, 冨田裕行*5

Kosei ISHIDA, Naruo KANO, Takeshi IGARASHI, Hirohiko FUJII, Yuji OOSAWA, Shintaro SAKAMOTO and Hiroyuki TOMITA

\begin{abstract}
In this paper, the authors describe a method of pre-cut components in finishing the interior works using 3D laser scanner.
To implement the pre-cut is required for the following three methods. Firstly, the authors develop the benchmark system for matching three coordinate system - existing building, point clouds and 3D CAD. Secondly, the authors develop the method of automatically seeking the couple of the targets for transforming the coordinates. Thirdly, the authors develop the design method by polygon model.
\end{abstract}

The authors scanned the reinforced concrete building and then applied those methods using 3D laser scanner

Keywords : 3D laser scanner, Point clouds, Pre-cut, 3D CAD, Reinforced-Concrete, Interior finish work 3次元レーザースキャナー，点群，プレカット，3次元 CAD，鉄筋コンクリート造，内装工事

\section{1. 緒言}

\section{1. 建築生産におけるプレカット化推進の必要性}

社会インフラの成熟と人口減少社会の到来に伴い、既存躯体を活 用し、内部の設備や内装を入れ替える大掛かりな改修工事の需要が 高まっている。改修工事では居ながら施工が求められることが多い ため、工事騒音や粉じんの原因となる現場切断や加工作業を行わず プレカット部材を用いて施工することが求められる。しかし、改修 工事では竣工図の紛失などで図面が得られないことも多く、使用す る部材の寸法や形状を事前に正確に把握することが出来ない問題点 がある。また、躯体等の既存部分には通常、施工誤差が存在するた め、たとえ竣工図が存在してもそれに基づいて部材を事前に切断・ 加工して既存部分の寸法・形状に合致するように取り付けることは 難しい。

また、新築工事においても、都市部での騷音の低減や生産性の向 上を目指してプレカット化を進めようとする動きもあり、如何にプ レカット部材を取り付け位置の寸法や形状に合わせて正確に切断・ 加工するかが大きな課題となる。

\section{2. 躯体の点群データの活用による内装エ事のプレカット化}

内装部材のプレカット化においては躯体形状を正確に把握するこ とが必要となる。特に施工誤差の生じや寸い鉄筋コンクリート造に おいてもプレカット化を実現するには、躯体の形状を 3 次元レーザ ースキャナーによって取得し、形状を記録した点群データを設計 CAD データに取り込んで、躯体形状に合わせて内装部材を設計し、 この設計データから部材の正確な加工寸法を施工前段階において把 握する必要がある。

この内装部材のプレカット化を実現するためには、以下の手順が 必要である。

（1）３次元レーザースキャナーを用いた躯体形状の計測

（2）内装部材の生産設計に適した点群データの処理

（3）点群データに基づく躯体のポリゴンモデルの作成

（4）ポリゴンモデルを用いた間仕切り壁部材の設計

\section{3. 既往の研究}

鉄筋コンクリート造の内装工事の合理化を目指した研究として横 山ら 1) は集合住宅において内装・設備の部品をユニット化すること で、専門職でない作業者でも施工可能な簡易施工部品による内装構 法を考案し、多能工による内装設備の一貫施工を実現している。三
*1 早稲田大学理工学術院創造理工学部建築学科 助手

*2 早稲田大学理工学術院創造理工学部建築学科 教授. 工博

*3 早稲田大学理工学術院総合研究所 客員教授. 博士 (工学)

*4 前田建設工業(株建築設計第 1 部

*5 新菱冷熱工業株)中央研究所
Research Assoc., Waseda Univ.

Prof., Dept., Waseda Univ., Dr. Eng.

Visiting Prof., Waseda Univ., Ph. D. (Eng.)

Building Design Dept., Maeda Corporation

R \& D Center, Shinryo Corporation 
根ら 2)344) は内装・設備工事の工程に関して調整・分析を行い、内装 工事の工程を明らかにするとともに、研究により得られた知見を基 にリブパネル構法を考案している。永尾ら5) は従来のパネル工法よ りも在来軸組工法に近い工法として間仕切り壁パネル工法を開発し ている。しかしながら、躯体の凹凸、特に床や天井の躯体面に凹凸 があるため、ユニット化した部材を如何に躯体面に追従させるかが 課題となることを指摘している。

現在では躯体の形状把握については 3 次元形状を正確に計測出来 る 3 次元レーザースキャナーが登場し、躯体の凹凸を事前に把握す ることが可能となっている。

建築生産における 3 次元レーザースキャナーの活用は施工の進捗 管理と出来形の確認を目的として、嘉納ら ${ }^{6)}$ が出来形を計測した点 群データと 3 次元 C A D モデルを比較することにより内装部材の取 り付け精度確認を行っている。佐藤ら 7)は 3 次元レーザースキャナ 一による大規模建築物の曲面外壁の施工精度の確認を実施している。 また、竹内ら ${ }^{8)}$ は 3 次元レーザースキャナーを用いて、建設現場の 作業進捗のモニタリングを実施するとともに 3 次元レーザースキャ ナーの鉄筋検查への適用 9)を試みている。印藤ら 10) は福島第一原子 力発電所の建屋カバーの建設に際して、建屋を 3 次元レーザースキ ヤナーで計測し、建屋カバーの設計に活用している。

\section{4. 本研究の目的と項目}

本研究は LGS とせっこうボードによる在来工法を 3 次元レーザ ースキャナーによる躯体計測によってプレカット化する研究である。 そのため本研究は躯体の計測、設計に至る一貫した手法の開発を目 指している。

内装部材のプレカット化を実現するためには、点群データから作 成したポリゴンモデルを用いて内装部材の生産設計を行い、現場に おいて適切な位置に設置するために地墨の位置の記録を軸とした 「施工箇所」「点群データ」「設計 $\mathrm{CAD} 」 の 3 つ の$ 空間座標を一致さ せる手法が必要となる。また、躯体を涱なく計測するために複数回 の計測が必要であるが、複数の点群データを効率的に座標統合寸る 手法が必要である。加えて鉄筋コンクリート躯体の 3 次元形状を記 録したポリゴンデータを用いた詳細設計手法の考案が必要である。 そのため本研究では以下の 3 つの手法を開発し、その実証実験を行 った。

(1) 施工箇所、点群データ、設計 $\mathrm{CAD}$ の空間座標の統合手法

（2）異なる座標系にある座標統合用ターゲットの自動対応手法

（3）ポリゴンデータを用いた部材の詳細設計手法

\section{2. 点群データを用いた既存躯体の形状把握とプレカット部材の設計}

\section{1. 3 次元レーザースキャナーを用いた躯体形状の計測}

3 次元レーザースキャナーを用いた計測では計測対象を隈なく計 測するために、複数回の計測を行うことが必要である。また、生産 設計に基づいて作成した部材を躯体に取り付けるには、プレカット 部材と躯体の設計誤差を $2 \sim 3 \mathrm{~mm}$ に抑える必要がある。3 次元レー ザースキャナーにより取得される点群データ 1 つ 1 つは数 $\mathrm{mm}$ の 誤差を持つ。だが、点群データの誤差は正規分布しているため、躯 体面での計測点を十分な密度に保つことにより最小化できる。また、 後述するように 3 次元レーザースキャナーは地墨や水平面の記録が 行えないため、地墨や水平面を表すターゲットを用いる必要がある。

\section{2. 部材のプレカットのための点群データの処理と点群データに 基づく躯体のポリゴンモデルの作成}

複数個所から計測した場合、点群データを同一の座標系に統合寸 る必要がある。また、3 次元レーザースキャナーにはチルトセンサ 一が付いていないため、陸墨の位置を図 1 に示寸平板ターゲットに より記録し、このターゲット位置に基づいて点群データの水平補正 を実施する。

これらの処理を実施したのち、内装部材の設計において使用する 躯体部分の点群データをポリゴンモデルへ変換する。なお、ポリゴ ン化の際に個々の点群のバラつきを収束させる必要があるため、ポ リゴン化に際しては点群データの空間密度を均一にしてからポリゴ ン化を行う必要がある。

\section{3. ポリゴンモデルを用いた間仕切り壁部材の設計}

躯体の 3 次元形状を反映したポリゴンモデルを設計 $\mathrm{CAD}$ に読み 込み、部材の詳細設計を実施する。従来の設計においては、部材は 現場合わせとするため個々の部材の寸法や形状を正確に設計図の中 に示す必要は無かった。しかし、プレカット部材を使用するには、 これら一つ一つの部材を正確な寸法・形状で図面として事前に求め ておくことが必要になる。このような詳細設計を実施するには下記 の 2 つの条件を満たすことが必要である。

（1）ポリゴンデータに施工箇所の通り芯が記録されている

(2) 設計 CAD とポリゴンデータの座標系が一致している

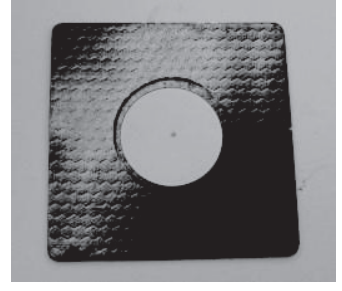

図 1 平板ターゲット

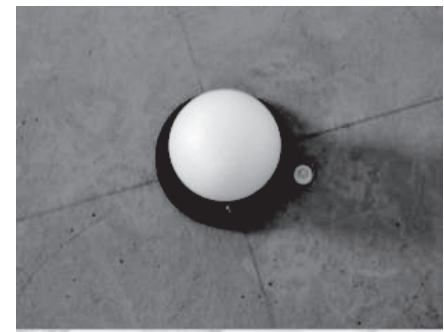

図 2 通り芯に設置した球ターゲット
3. 空間座標の統合手法とポリゴンモデルを用いた設計手法 3. 1. 施工箇所、点群データ、設計 CAD の空間座標の統合手法

\subsection{1. 点群データに記録されない情報の記録方法}

3 次元レーザースキャナーによる計測で取得できる点群データは $\mathrm{XYZ}$ 座標とレーザーの反射輝度からなる。また、カメラが内蔵され ているタイプの 3 次元レーザースキャナーでは、レーザー照射点の 色情報を RGB で取得することも可能である。ただ、輝度は計測対 象までの距離と、照射点へのレーザーの入射角によって変化し、 $\mathrm{RGB}$ は 3 次元レーザースキャナーの設置個所の明るさや計測対象 の状態によって変化するため、安定的なデータを取得できない。特 に、薄暗い建築現場において地墨のように黒色によって身体に記録 されている情報の取得は難しい。

そのため、プレカット部材の取付け位置と関係する、記録できな い情報には下記のものがある。

（1）陸墨（水平面）

（2）地墨（通り芯）

水平面の記録については、レーザー水準器などを用いて、陸墨を 出し、平板ターゲットの中心をこの陸墨上に 4 か所以上設置するこ 
とで記録を行う。

\section{1.2. 地墨の取得}

地墨を取得するには床面に直接、平板ターゲットを設置して地墨 の位置を記録する方法もあるが、3 次元レーザースキャナーから夕 ーゲットへ照射されるレーザー光の入射角が大きくなりすぎる場合 も多く、正確にターゲットの中心位置が取得できない。

そこで、この地墨の位置を点群データに記録するために球状の夕 ーゲットを開発した。

地墨取得用ターゲットの写真を図 2 に、設計寸法を図 3 に示す。 このターゲットは白い球体である「球ターゲット」と球ターゲット を載せる「台座」から成る。台座は磁性をもつステンレス鋼である SUS430 で構成され、中心に真円の穴の開いたドーナッツ形状をし ている。球ターゲットの底面には磁石が埋め込まれているため、台 座の上に球ターゲットを安定的に据えることが出来る。台座の中心 には穴が開いており、その底面にはプラスチック板が装着され、円 形の穴の中心がけがかれている。このプラスチック板の中心と台座 の球ターゲット設置部分の真円の中心と球の中心が一直線上に来る ような構造になっており、台座の上面の水平度を担保した状態で設 置すると、球の中心が地墨の鉛直方向に正確に設置可能になってい る。なお、台座の水平は脱着可能な円形気泡管により保たれている。

この球ターゲットの中心座標を最小二乗法によって求め、水平補 正後に点群データから求めた床面に鉛直方向に投影することで、通 り芯を求める。球は直径が $100 \mathrm{~m}$ m であり、台座の高さも $20 \sim 30$ $\mathrm{m} m$ ほどであるため、球の中心は床面から $100 \mathrm{~mm}$ 以内の高さに存 在する。そのため、台座の水平のズレが $0.5^{\circ}$ 以下であれば表 1 に 示寸如く、地墨の位置を $1 \mathrm{~mm}$ 以内の誤差で取得可能である。

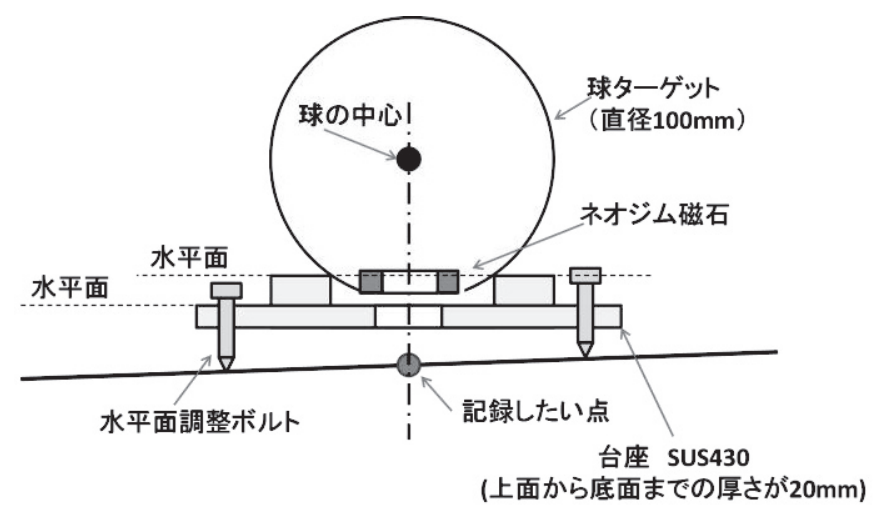

図 3 球ターゲットの概要図

表 1 球ターゲットの精度 ( $\mathrm{mm})$

\begin{tabular}{|c|c|c|c|c|c|c|c|}
\hline \multicolumn{2}{|c|}{ 角度(度) } & 0.020 & 0.100 & 0.200 & 0.500 & 0.800 & 1.000 \\
\hline 中心の床面 & $70 \mathrm{~mm}$ & 0.024 & 0.122 & 0.244 & 0.611 & 0.977 & 1.222 \\
\hline からの高さ & $80 \mathrm{~mm}$ & 0.028 & 0.140 & 0.279 & 0.698 & 1.117 & 1.396 \\
\hline$(\mathrm{mm})$ & $100 \mathrm{~mm}$ & 0.035 & 0.175 & 0.349 & 0.873 & 1.396 & 1.746 \\
\hline
\end{tabular}

\section{2. 異なる座標系にある座標統合用ターゲットの自動対応手法}

3 次元レーザースキャナーはスキャナー本体からレーザー光を直 接、照射できる範囲しか計測できないため、計測対象を隈なく計測 するには複数回、計測する必要がある。その際、座標統合用に使用 するターゲットは複数存在し、計測位置によって使用する座標統合
用ターゲットは異なる。また、地墨や陸墨の記録においてもターゲ ットを使用するため、各計測位置のデータには複数のターゲットが 存在している。座標統合の際には異なる計測位置から取得したター ゲットのうち、同一のターゲットを計測したペアを事前に対応させ ておく必要がある。この対応を手作業で行うのは手間がかかるとと もに対応付けのミスを誘発するため、計測位置ごとのターゲットを 自動的に対応させる手法を考案した。
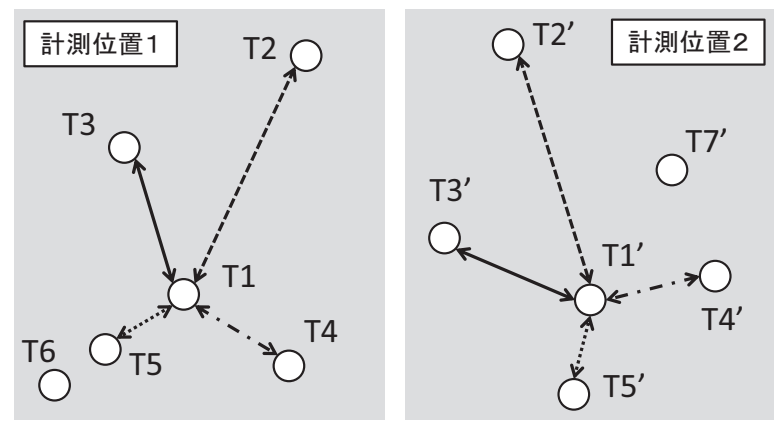

図 4 異なる座標系にある同一ターゲットの相互距離の同一性

座標統合用ターゲットの自動対応は同一のターゲットを複数個計 測した場合、異なる座標系であってもターゲットの配置位置は図形 的に合同であるため、図 4 に示寸如く対応するターゲット間の距離 はほぼ等しくなる原理を利用している。座標統合を行うには 4 つ以 上のターゲットを同定することが必要であるため、ターゲットの相 互距離が 3 つ以上で一致したものを選択寸ればよい。また、相互距 離であるため、正しくない組み合わせであっても相互距離が一致す るものが 1 つ以上存在する。そのため、相互距離が最も多く一致す るものをターゲットのペアとして対応させる。

計測位置 1 から取得した $\mathrm{m}$ 個のターゲット群を $\mathrm{T} 1$ 、計測位置 2 から取得した $\mathrm{n}$ 個のターゲット群を $\mathrm{T} 2$ とした時、ターゲットの対 応を自動的に行うには下記の手順を経る。またこの手順を図 5 に示 す。

(1) $\mathrm{i}=1$ とする

(2) T1(i)に対応するターゲットを T2 から探す。まず T1(i)を MainPoint とし、T1(i)と T1(i)以外の T1 のターゲットとの相 互距離を求め、変数 $\mathrm{T} 1 \operatorname{dis}(\mathrm{j})(\mathrm{j}=1 \sim \mathrm{m} 、$ ただし $\mathrm{j} \neq \mathrm{i})$ に記録する (3) $\mathrm{j}=1$ とする

(4) T2 $(\mathrm{j})$ を SubPoint とし、 $\mathrm{T} 2(\mathrm{j})$ と $\mathrm{T} 2(\mathrm{j})$ 以外の $\mathrm{T} 2$ のターゲットと の相互距離を求め、変数 $\mathrm{T} 2 \operatorname{dis}(\mathrm{k})(\mathrm{k}=1 \sim \mathrm{n}$ 、ただし $\mathrm{k} \neq \mathrm{j})$ に記録 する

（5）T1 に含まれる MainPoint の相互距離 T1dis と T2 に含まれる SubPoint の相互距離 T2dis を総当りで比較する。 $\mathrm{k}$ 番目の T1dis と 1 番目の T2dis の值の差である $|T 1 \operatorname{dis}(k)-T 2 \operatorname{dis}(l)|$ が基準值 $\alpha$ より小さくなるペアの数をカウントし、これを $\mathrm{K} \alpha$ とする。 SubPoint である T2(j)のペア数を Pair $(\mathrm{j})$ に記録し、 $\mathrm{j} \leftarrow \mathrm{j}+1$ とし て $\mathrm{j} \leqq \mathrm{n}$ ならば (4)に戻る。 $\mathrm{j}=\mathrm{n}+1$ となったら (6)に進む。

(6) Pair(j) (ただし j=1 n)の中から最も大きな数となるものを探し、 そのときの $\mathrm{j}$ を $\mathrm{jMax}$ とする。

(7) Pair(jMax)が 3 以上であれば(つまり相互距離が一致するペアが 
3 つ以上存在するのであれば） $\mathrm{T} 1(\mathrm{i})$ と $\mathrm{T} 2(\mathrm{jMax})$ は同一のターゲ ットであると判定し、T2'(i)に T2(jMax)を記録する。i $\leftarrow$ i 1 と して $\mathrm{i} \leqq \mathrm{m}$ ならば（2)に戻る。 $\mathrm{i}=\mathrm{m}+1$ となったら(8)に進む。

(8) (1) (7)の繰り返しにより見つかった対応するターゲットが m’個 であるとき、この $\mathrm{T} 1$ と $\mathrm{T} 2$ ’を用いで座標統合注 1$)$ を実施する。座 標統合による $\mathrm{T} 1$ と $\mathrm{T} 2$ 'の対応するターゲット同士の距離の平均 が許容值以下であれば座標変換を実施する。

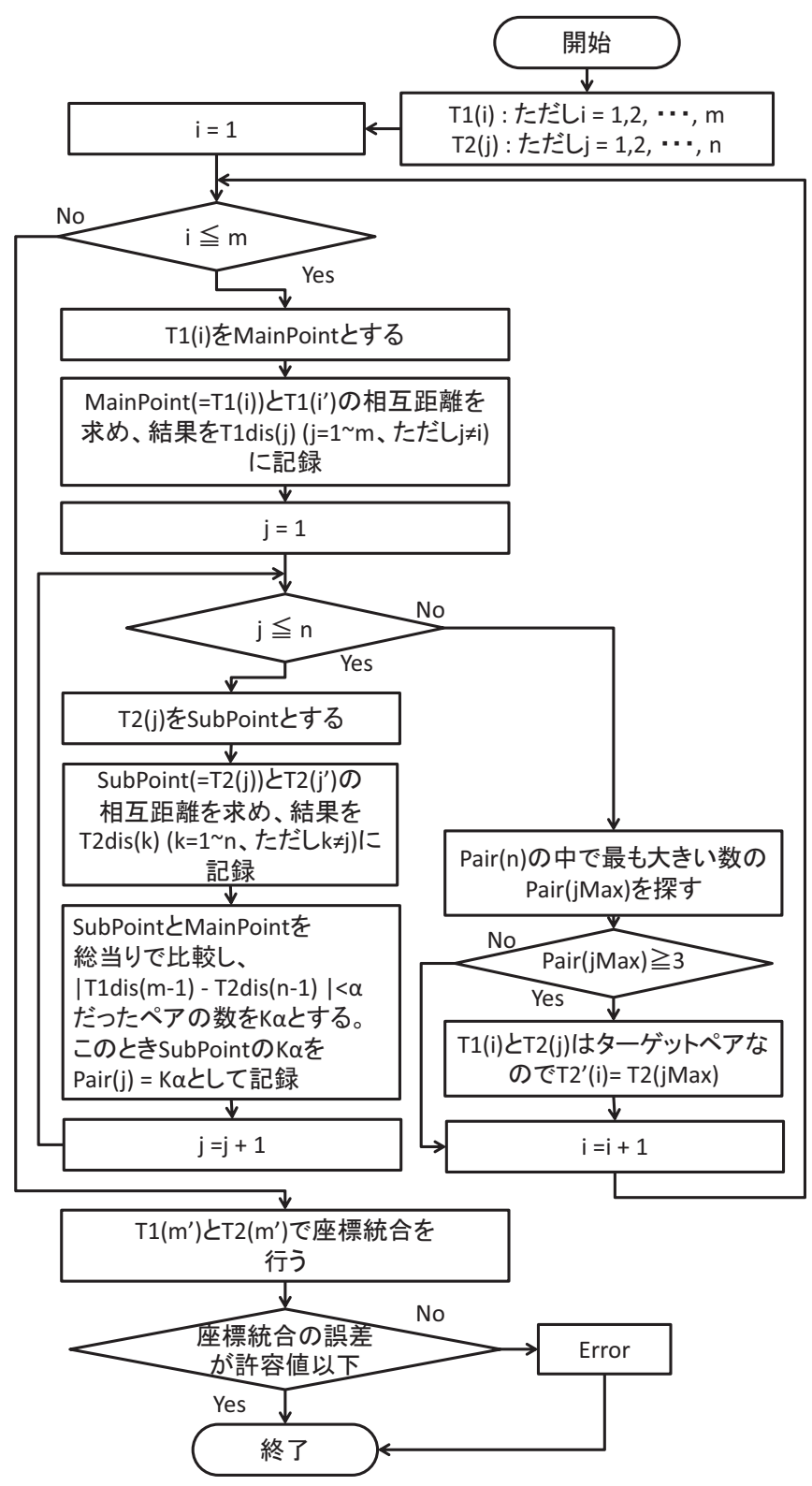

図 5 座標統合用ターゲットの対応の自動化手法の処理フロー図

ただし、通り芯の交点に球ターゲットを設置して、この球ターゲ ットを座標統合用ターゲットとする場合、図 6 に示寸如く、ターゲ ット間の距離に差の少ない組み合わせが多い配置となる。そのため、 図 6 のように判別用ターゲットを設置する。判別用に規則性をずら したターゲットが 1 つ以上存在することによって、相互距離のペア が正しく選別できるようになる。

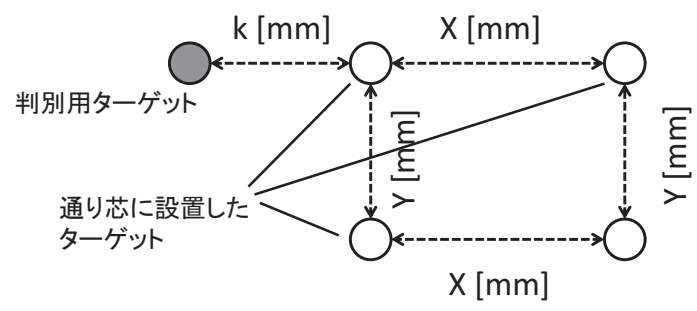

図 6 判別用ターゲットの配置

\section{3. ポリゴンデータを用いた部材の詳細設計}

従来、建築工事においては内装部材の配置位置やボード材の割り 付けと加工寸法は建築工事標準仕様書や作業要領書の規定に基づい て、現場作業者の判断によって決められている。これは躯体の凹凸 を設計時点で把握することが困難であったためである。本研究では 3 次元レーザースキャナーにより取得した点群データから躯体の 3 次元形状を反映したポリゴンモデルを作成しているため、設計時点 で躯体の 3 次元形状に基づいたプレカット部材の作成が可能になる。 ポリゴンモデルを用いて内装部材の詳細設計を行うために「面墨」 という概念を導入している。2 次元図面での設計では通り芯や壁芯 などの基準線を引き、設計を行っている。面墨とはポリゴンモデル を用いる 3 次元 $\mathrm{CAD}$ 上での設計において基準線を 3 次元に拡張し たもので、間仕切り壁の設計においいて間仕切り壁の中心部分にこ の面墨を図 7 に示す如く配置する。

躯体形状を反映したポリゴンモデルと面墨を用いて、壁厚が $\mathrm{X}(\mathrm{mm})$ である間仕切り壁の設計手順を以下に示す。また、この時の 各部分の名称を図 8 に示す。

(1)設計 CAD に読み込んだポリゴンデータにおける地墨の位置を 設計 $\mathrm{CAD}$ 上の XY 座標に合わせる。

(2)壁面を設置する位置に、面墨を配置する。この面墨は鉛直面で、

XY 平面上にある間仕切り壁の通り芯を通る面である。

(3)面墨から法線方向に $\mathrm{X} / 2$ の範囲にあるポリゴンモデルを切り 出し、面墨がある平面上に法線方向で投影する。

（4）面墨上に投影された壁面の断面線に従い、軸組部材を配置する。 軸組材のスタッドの長さは断面線より求めた長さより $\mathrm{Kmm}$ 短 くする。

（5）軸組部材と同様に躯体の断面線を用いて面材であるせっこう ボードの割り付け図を作成する。その後、定尺材からの加工図を 作成する。

なお、(4)にある $\mathrm{Kmm}$ 短い長さで設計する理由は、ランナーにス タッドをはめるためである。

この長さ K は下記の方法で算出する。

床面から天井面までの高さをLs、ランナー側面の高さをZ とし、 ランナーにスタッドをはめるための隙間を X、ランナーが躯体の変 形には完全に追従できないことによって、ランナーと躯体面との間 に生じる隙間を Y とした時、長さ K は

$$
\mathrm{X}+\mathrm{Y} \leqq \mathrm{K} \leqq \mathrm{Z} \quad \text { ただし } \mathrm{K}+\mathrm{L}=\mathrm{Ls}
$$

となるように $\mathrm{K}(\mathrm{mm})$ 分、スタッド長さを短くする。なお、 $\mathrm{Z}$ が $30 \mathrm{~mm}$ 程度の製品の場合、 $\mathrm{K}$ は $10 \mathrm{~mm}$ 程度を想定している。 


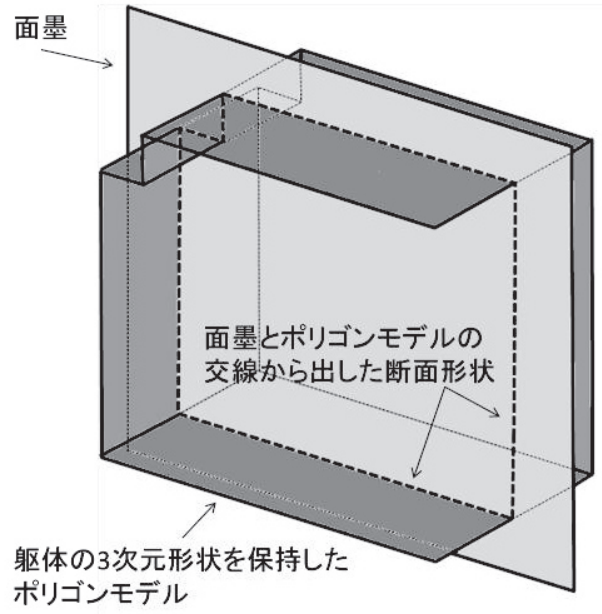

図 7 壁面設置位置の躯体断面形状を算出するための面量

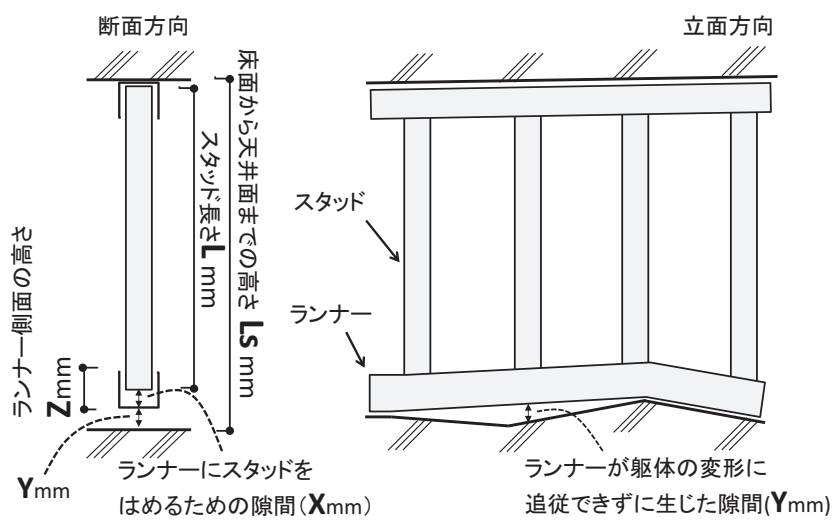

図 8 ポリゴンモデルからのスタッド長さの算出方法

\section{3 次元レーザースキャナーを用いた間仕切り壁改修工事の実験}

\section{1. 既存躯体の計測}

\subsection{1. 計測実験の概要}

適用事例として、事務所建築の一室を対象として、施工実験を実 施した。改修工事における、内装間仕切り壁工事を想定している。 図 9 右に示す間仕切り壁を作成する。

本実験において内装間仕切り壁は躯体に直接取り付ける構法を想 定しているため、内装間仕切り壁を設置する個所の既存内装材は解 体した状態で実験を行った。建築物の概要と実験を実施した期間を 表 2 に示す。

表 2 建築物の概要と実験を実施した期間

\begin{tabular}{cc}
\hline 用途 & オフィス \\
\hline 構造 & $\mathrm{RC}$ 造 \\
\hline 測定籄所 & 会議室 $($ 階高 約 $4000 \mathrm{~mm})$ \\
\hline 実験実施期間 & 2010 年 11 月 29 日 2010 年 12 月 17 日 \\
\hline
\end{tabular}

\section{1. 2. プレカット部材を作成するのに必要な情報}

本実験において求める数量・寸法情報は下記の如くである。

（1）ランナーの本数・長さ
(2) スタッドの本数・長さ

(3) せっこうボードの加工形状

上記の数量・形状情報を取得するには、間仕切り壁と躯体とが接 する位置の躯体の 3 次元形状が必要である。

また、3 次元 $\mathrm{CAD}$ を用いて設計した間仕切り壁の位置座標と実 際に間仕切り壁を設置する位置座標とを一致させるためのベンチマ ークを設置する必要がある。改修工事においては躯体に記された地 墨をベンチマークとするため、地墨の位置を点群データに記録する。

本実験において、3 次元レーザースキャナーを用いて下記の情報 を取得することとした。

（1）間仕切り壁と躯体とが接する部分の躯体の 3 次元形状

(2) 躯体の地墨の位置

（3）点群データにおける水平面

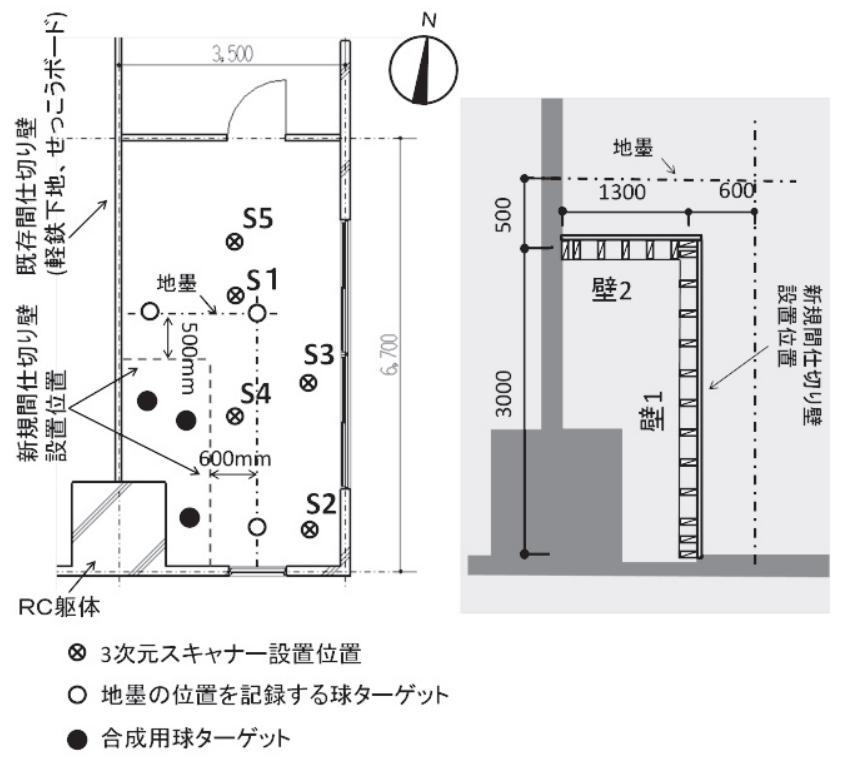

図 9 実験に使用した会議室に新設する間仕切り壁の平面図と 3 次元レーザースキャナーの設置位置
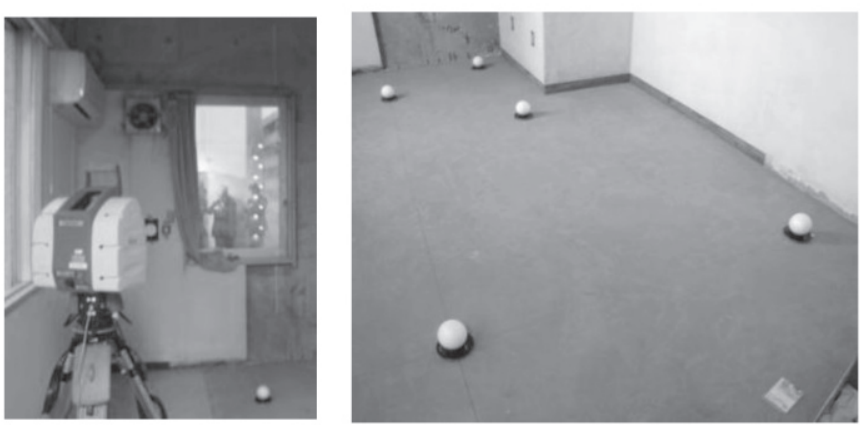

図 10 計測の状況と通り芯に設置した球ターゲット

\subsection{3. 本実験の要領}

本実験における計測の要領は下記の通りである。

(1) 測定間隔は $2 \mathrm{~mm}$

（2）レーザー水準器を用いて水平面の位置を記録する平板ターゲ ットを設置

（3）合成用の平板ターゲットの設置 
(4) 地墨の位置に、球ターゲットの設置

（5）３次元レーザースキャナーを用いた計測( 5 回)

図 9 左に示す位置に球ターゲットを設置し、S1 から S5 までの五 か所から計測を実施した。

5 か所から取得した点群データは、一つの座標系に統合され、水 平補正と躯体の通り芯に合わせた後、ノイズの除去を行った。これ により 5 か所から得た点群データが統合された、 1850 万点からなる 点群データを得た(表 3)。そして、間仕切り壁が触れる部分の躯体の 点群を取り出し、点群からポリゴンモデルを作成した。そしてこの ポリゴンデータを用いて、間仕切り壁の設計を行い、ランナーとス タッドの寸法、せっこうボード材の形状を求めた。

\section{2. 球ターゲットからの地墨の位置の取得}

躯体に墨出した x、y 方向の通り芯上に球ターゲットを設置し、 3 次元レーザースキャナーを用いて計測した。計測時の状況を図 10 に示す。球ターゲットを計測した場合、大量のノイズが生じるため 点群データから球の表面部分の点群データのみを抽出し、この球の 表面の点群データの座標から最小二乗法を用いて球近似を行い、球 ターゲットの中心座標を算出した。そして、この球ターゲットの中 心座標より点群データの通り芯位置を算出した。

取得した点群データは通り芯の向きが $\mathrm{CAD}$ の XY 座標系と合致 していないため、点群データの座標系を変換し、通り芯の向きを $\mathrm{CAD}$ の XY 座標系にあわせた。球ターゲットから点群データに記録 された通り芯を読み取った後、より距離の長い南北方向の通り芯を 設計 $\mathrm{CAD}$ モデルの $\mathrm{y}$ 軸に一致させた。

表 3 計測位置ごとの
点群数

\begin{tabular}{cc}
\hline $\begin{array}{c}\text { 計測 } \\
\text { 位置 }\end{array}$ & 点群数 \\
\hline $\mathrm{S} 1$ & $2,645,938$ \\
\hline $\mathrm{S} 2$ & $3,126,787$ \\
\hline $\mathrm{S} 3$ & $4,499,767$ \\
\hline $\mathrm{S} 4$ & $7,509,244$ \\
\hline $\mathrm{S} 5$ & 725,492 \\
\hline
\end{tabular}

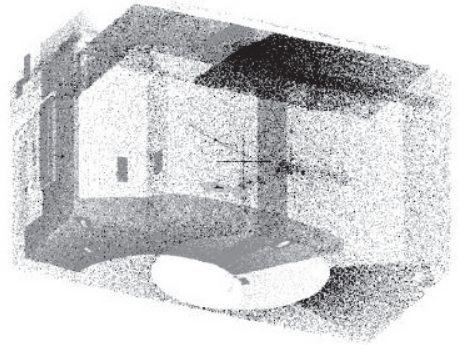

図 $115 つ$ 点群を統合した点群
表 4 ターゲットの自動対応と座標変換 $(\mathrm{mm})$

\begin{tabular}{c|ccc|ccc|c}
\hline \multirow{2}{*}{ 名称 } & \multicolumn{3}{|c|}{ S1 } & \multicolumn{3}{|c|}{ S3 } & \multirow{2}{*}{ 誤差 } \\
\cline { 2 - 7 } & $\mathrm{X}$ & $\mathrm{Y}$ & $\mathrm{Z}$ & $\mathrm{X}$ & $\mathrm{Y}$ & $\mathrm{Z}$ & \\
\hline T1 & 224.0 & 2462.3 & -228.4 & 223.4 & 2463.7 & -228.4 & 1.5 \\
\hline T2 & 1626.7 & 2539.2 & -227.9 & 1626.3 & 2540.7 & -227.8 & 1.5 \\
\hline T3 & 2230.1 & 1217.5 & -227.3 & 2230.3 & 1218.7 & -227.5 & 1.2 \\
\hline T4 & 2864.1 & -1232.9 & -228.4 & 2866.0 & -1234.0 & -228.2 & 2.2 \\
\hline T5 & 1507.6 & -4031.0 & -228.3 & 1507.4 & -4032.8 & -228.3 & 1.7 \\
\hline T6 & 206.2 & -4052.0 & -227.6 & 205.3 & -4053.2 & -227.6 & 1.6 \\
\hline T7 & & & & 1232.9 & -4037.6 & 812.7 & ---- \\
\hline T8 & & & & 2843.3 & 72.3 & 1009.2 & ---- \\
\hline T9 & -533.1 & -962.6 & -228.3 & & & & ---- \\
\hline
\end{tabular}

\section{3. ターゲットの自動対応と座標の統合}

本実験においては 5 か所から計測を実施した。実験に使用した部
屋には計 9 個の座標統合用の平板ターゲットを設置した。計測位置 によって取得できるターゲットは異なっているため、ターゲットの 自動対応手法を用いて、同一のターゲットの捜索を実施し、座標の 統合を行った。表 4 に S3 と S1 のターゲットの対応を行い、座標の 統合を実施した際の統合の誤差を示す。表 4 に示す如く、座標統合 によるターゲット間距離の差は最大で $2.2 \mathrm{~mm}$ 以下であり、自動対 応と座標統合が正常に行い得たことを確認することが出来た。

なお、表 4 の誤差とはS 1 とS3 の対応するターゲットの直線距離 を意味している。

\section{4. 点群データの計測精度}

水平補正と通り芯に基づいた回転、座標の統合を実施し、図 11 に示す統合点群を作成した。この点群データの計測精度を確認する ために、天井高さを手計測で取得し、点群データから求めた天井高 さとの比較を図 12 に示す箇所について行った。この比較結果を表 5 に示す。点群データと手計測の結果とは大きな差がないことが確認 できる。

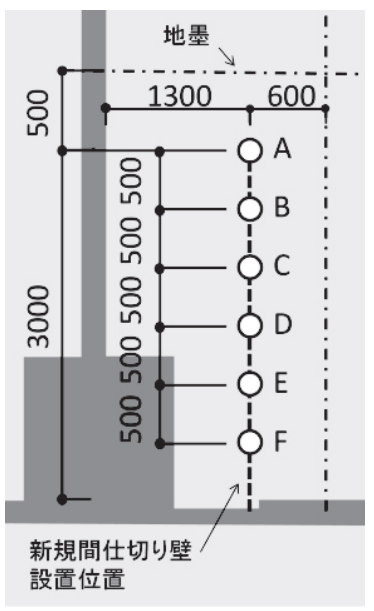

表 5 点群データから取得した天井高 さと手計測の比較 $(\mathrm{mm})$

\begin{tabular}{cccc}
\hline 位置 & 点群 & 手計測 & 誤差 \\
\hline A & 4005.9 & 4005 & 0.9 \\
\hline B & 4003.2 & 4000 & 3.2 \\
\hline C & 3996.9 & 3998 & -1.1 \\
\hline D & 3993.8 & 3998 & -4.2 \\
\hline E & 3198.1 & 3195 & 3.1 \\
\hline F & 3999.9 & 3997 & 2.9 \\
\hline
\end{tabular}

図 12 点群の精度の確認

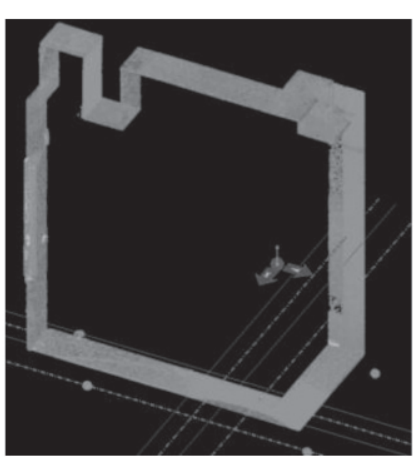

図 13 作成した点群データ

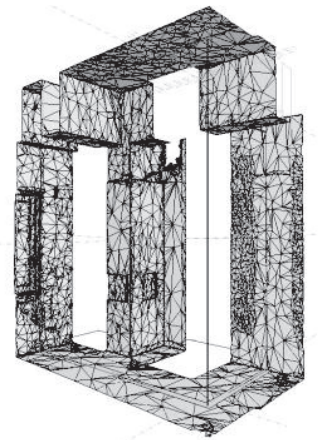

図 14 躯体のポリゴンモデル

\section{5. ポリゴンモデルによる間仕切り部材の設計}

複数の点群データの座標統合を行った後、間仕切り壁が接する部 分の躯体の点群を図 13 に示す如く切り出し、この点群データから 図 14 に示すポリゴンモデルを作成した。DXFデータで作成したポ リゴンデータを設計 $\mathrm{CAD}$ に読み込み、躯体の 3 次元形状を示すポ リゴンモデルに基づいて間仕切り壁のせっこうボードの生産設計図 面を作成した。設計においては間仕切り壁の設置位置を示す面墨を 
配置し、その後、図 15 に示寸如くランナー、スタッドとせっこう ボード材を設置する部分の躯体断面をポリゴンデータから作成した。 この設計断面からランナー、スタッドとせっこうボードの加工寸法 を求めた。今回、使用したランナーの側面高さは $30 \mathrm{~mm}$ である。躯 体床面と天井面の局所的な凹凸は数 $\mathrm{mm}$ 程度であったので、スタッ ドは設置位置の床と天井の距離より $10 \mathrm{~mm}$ 短くなるように設計し た。作成したランナーとスタッドの $\mathrm{CAD}$ モデルを図 16 に示す。せ っこうボードは図 17 に示す如く、躯体の形状をそのまま反映した 形状となるように設計を行った。図 18 に示寸如く、せっこうボー ドの形状が定まった後、3×6 版の定尺材から切り出す加工図を図 19 の如く作成し、これを原寸図として大型プリンターで出力し、こ の原寸図を型紙として、せっこうボードのプレカット部材を作成し た。
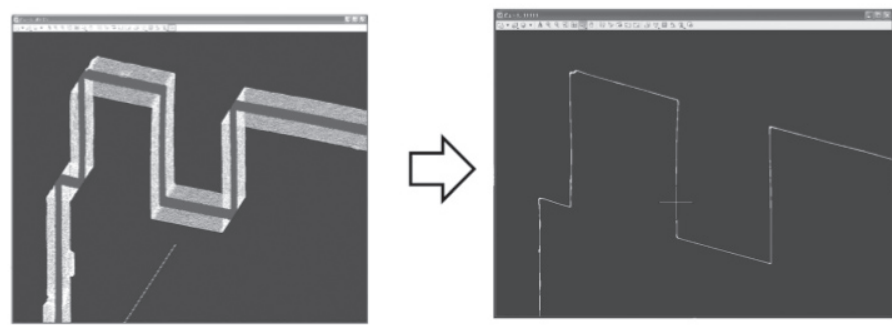

図 15 ポリゴンデータからの設計断面の作成

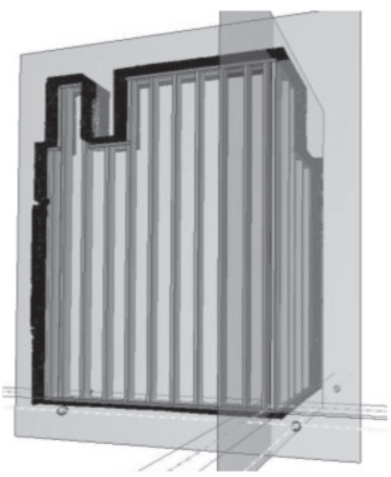

図 16 面墨で設計したスタッド

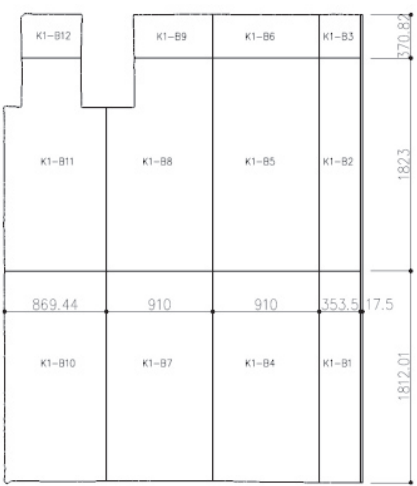

図 18 せっこうボード材の 割り付け図

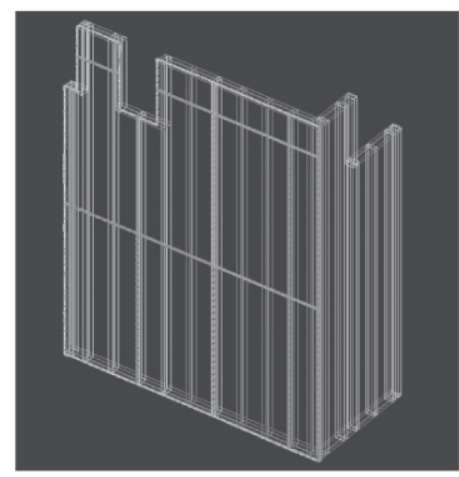

図 17 間仕切り壁の 3 次元 $\mathrm{CAD}$ モデル

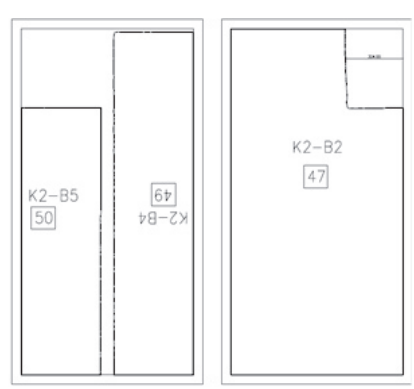

図 19 定尺せっこうボードの加 工図

\section{6. 部材の加エと取り付けと精度の検証}

\subsection{1. スタッドの加エ・取り付けと精度}

図 22 に示寸如く、プレカットしたランナーとスタッドを取り付 けた。スタッドの取り付け後、ランナーとスタッドの隙間を実測し た結果が図 20 である。設計時にはランナーとスタッドの隙間を、 施工誤差や作業性を考慮して $10 \mathrm{~mm}$ としたが、実験の結果ではラン ナーとスタッドの隙間の実測值は平均值 $4.3 \mathrm{~mm}$ と、設計值を $5 \mathrm{~mm}$ 程 度下回った。隙間が当初の設計よりも $5 \mathrm{~mm}$ 短くなった原因は、床 や天井の不陸にランナーが完全には追随していないためと考えられ る。

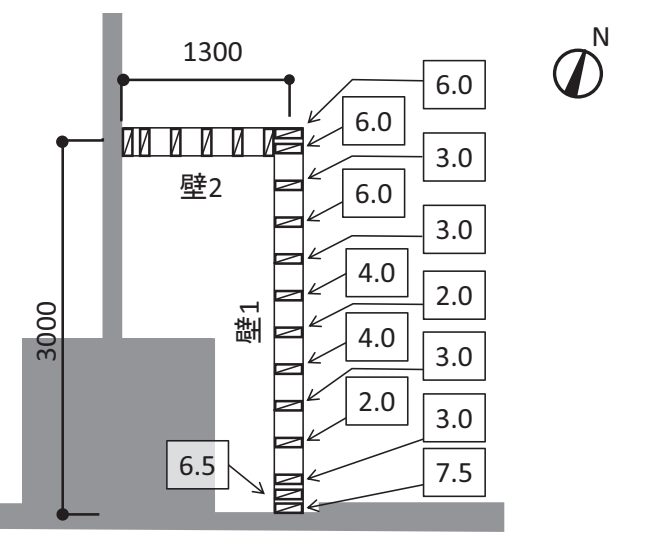

図 20 設置したスタッドとランナーの隙間の実測結果 $(\mathrm{mm})$

\section{6. 2. せっこうボードの加エ・取り付けと精度}

せっこうボードの加工においては、原寸図を型紙として使用し、 せっこうボードに張り付けそれに沿って部材の切り出しを行い、更 にヤスリ掛けによって原寸図に忠実に加工した。図 21 に示す如く、 プレカットしたせっこうボードは躯体にピッタリ納まっていた。

本実験で作成した間仕切り壁は高さが約 $4000 \mathrm{~m}$ で $3 \times 6$ 版のせっ こうボードを縦使いで割り付けているため、せっこうボードは図 18 に示す如く上部、中部、下部の 3 段で割り付けている。取り付けに おいては既存躯体の壁側から下部のボードを全て取り付けたが、角 部に取り付けるコーナー材とせっこうボードの間に $1 \mathrm{~mm}$ 隙間が生 じた。また、上部のせっこうボード取り付けにおいては、せっこう ボードの高さ方向の寸法が 1 2mm 程度大きく、そのままでは嵌ら なかったため、せっこうボードの一部をヤスリで削り、取りつけた。 この誤差の原因は、せっこうボードの寸法製造誤差(約 $\pm 2 \mathrm{~mm}$ )、原 寸図の印刷による用紙の伸び縮みおよびプリンターヘッドの位置の 誤差(約 $\pm 1 \mathrm{~mm} \sim 2 \mathrm{~mm}$ )、躯体の計測誤差(約 $\pm 2 \mathrm{~mm}$ )の 3 つの原因が 存在すると考えられる。せっこうボードの寸法製造誤差や原寸図の 誤差は、せっこうボードの加工を行った後に再度、加工寸法の確認 を実施することで取り除くことが可能である。また、今回使用した 3 次元レーザースキャナーの公称誤差は $6 \mathrm{~mm}$ であるが、高密度計 測によって点群の誤差を最小化することが可能であることを確認で きた。技術進歩によってより計測精度の高い 3 次元レーザースキャ ナーが登場することによって計測誤差に関しても、解決すると考え られる。

せっこうボードのプレカット部材により作成した間仕切り壁を図 23 に示す。 

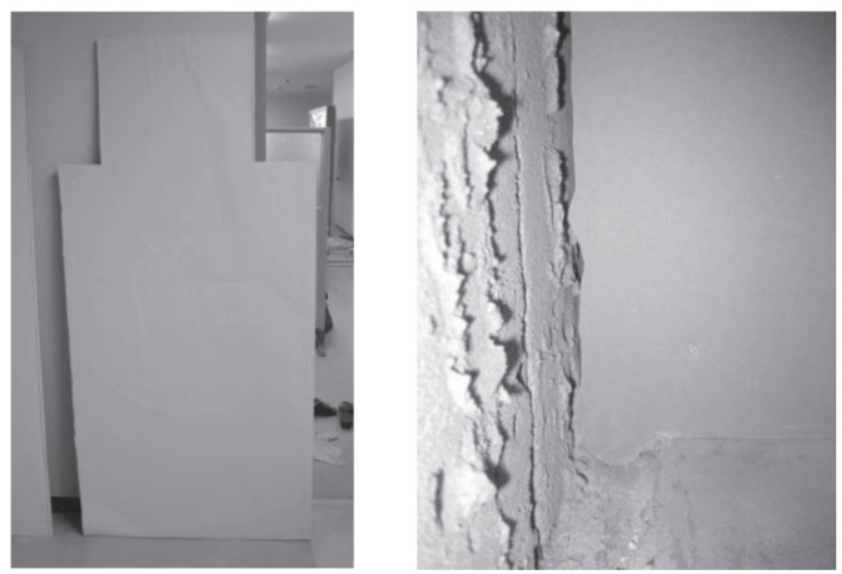

図 21 プレカットしたせっこうボードと躯体の凹凸に合った ボード材の設置の様子

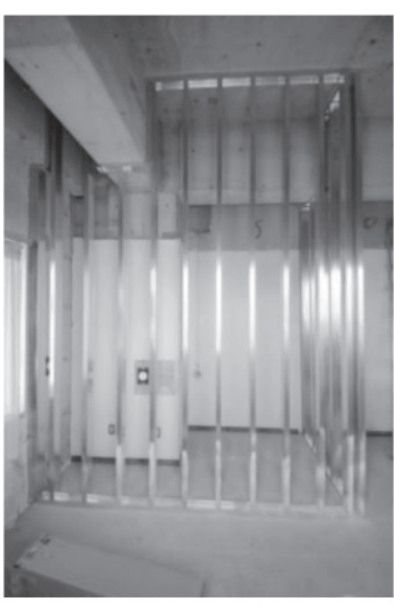

図 22 軽鉄下地材の出来形

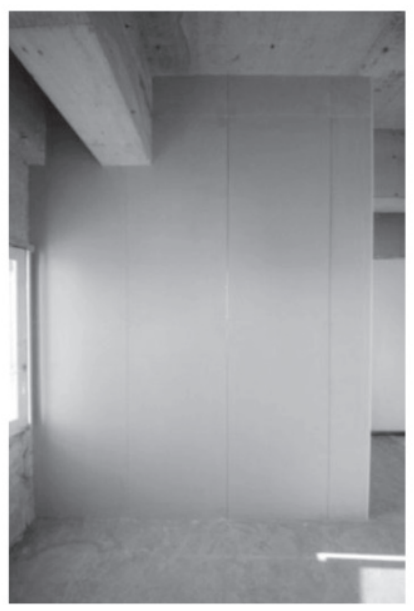

図 23 ボード材の出来形

\section{5. 結言}

3 次元レーザースキャナーによって取得した点群データからポリ ゴンモデルを作成し、ポリゴンモデルに基づいて切断・加工したプ レカット部材を用いて内装間仕切り壁の施工実験を行った。これに より点群データから作成したポリゴンモデルが実際の躯体の寸法を 正確に記録していることが確認できた。また、点群データの座標系 と $\mathrm{CAD}$ データの座標系とを一致させるベンチマークとして、地墨 の位置を記録するための球ターゲットを考案し、正確に点群データ、 設計 $\mathrm{CAD}$ 、施工箇所の座標系を一致させることが出来た。さらに本 報で示した手順によって取り付けたせっこうボードの目地を水平面 で揃えることが出来ることを確認した。これは、点群データに水平 面の位置を平板ターゲットにより記録するとともに、躯体をポリゴ ンデータとして正確に記録でき、かつ点群データ、設計 $\mathrm{CAD}$ 、施工 箇所の座標系が正確に一致していることを示している。

本研究において提案した 3 つの手法を用いることで、改修工事に おける部材のプレカット化を実施するために必要な、既存躯体の形 状に合致させる部材を事前に切断・加工することが出来ることを確 認した。これにより、3 次元スキャナーを用いた内装部材のプレカ ット化が技術的に可能であることが確認できた。

なお、本研究では 2000 年代初頭に販売が開始された 3 次元レー
ザースキャナーを使用しているため、計測に 7 時間程度を要したが、 最新機器では毎秒数十万点の計測が可能となっているため、本研究 と同様の計測は、ターゲット設置や移設も含め 1 時間程度で可能で ある。

また、点群データの処理とポリゴンモデルの作成は約 12 時間を 要したが、本報で示した一連の点群処理プロセスを自動的に実施す るシステムを開発することで、更なる効率化と省力化が可能である。

しかしながら、本手法を実用化する際に課題となる点としては、 従来は現場作業者が軸組材の配置やボード材の割り付けを考えて、 その場で部材を加工・配置していたが、本手法では生産設計段階に おいて軸組材の配置とボード材の割り付けを事前に決める必要があ る点が挙げられる。数多くの軸組材の詳細な配置位置と、それぞれ のボード材の割り付け・部材形状を求めるには、これらをコンピュ 一タ内で自動的に実施し得る新たな設計アルゴリズムが必要となる。

\section{謝辞}

本研究は、国土交通省平成 $21 \cdot 22 \cdot 23$ 年度住宅・建築関連先 導技術開発助成事業によって実施した成果である。

\section{参考文献}

1）横山謙司、三根直人、高世厚史、岡建雄 : 部品のユニット化と多能工施工 による住宅内装設備施工の合理化に関する研究、日本建築学会技術報告集 第 13 号、pp. 175-180, 2001.7

2）三根直人、高田博尾、椚隆：内装・設備工事の工程分析 集合住宅におけ る内装工事に関する研究 その 1、日本建築学会計画系論文集 第 534 号、 pp. $233-240,2000.8$

3）三根直人、椚隆 : 内装・設備工事の工数と工数からみた工程の特徴 集合 住宅における内装工事に関する研究 その 2、日本建築学会計画系論文集 第 564 号、pp. 263-270, 2003.2

4）三根直人、椚隆 : 内装・設備工事における作業の習熟効果 集合住宅にお ける内装工事に関する研究 その 3、日本建築学会計画系論文集 第 568 号、 pp. 109-116, 2003. 6

5）永尾真、宗永芳、安間由倫：間仕切り壁パネル工法の開発 集合住宅にお ける内装工事の生産性向上、日本建築学会技術報告集 第 20 号、pp. 27-30、 2004. 12

6）嘉納成男, 河原吉則, 柿崎甫, 石岡宏晃:建築生産における 3 次元スキャナ 一の活用に関する研究 -3 次元スキャナーによる出来形と工事進捗の計測第 25 回建築生産シンポジウム論文集、pp187-192、2009.07

7）佐藤康弘，長瀧慶明：新時代を拓く最新施工技術(第 15 回)建築分野にお ける三次元レーザスキャナーの活用事例、建築技術 第 732 号, pp68-75, 2011. 1

8）竹内啓五、太田達見: 簡易型形状取得装置による建物施工モニタリング技 術の検討、日本建築学会大会学術講演梗概集、A-1、pp953-954、2011.8

9）竹内啓五、太田達見：鉄筋観測のための小型形状スキャナの適用性評価、 日本建築学会大会学術講演梗概集、A-1、pp193-194、2012.9

10）印藤正裕，梶波信一，西川裕他：福島第一原子力発電所 1 号機 原子炉建 屋力バー工事の取組み(その 1) 構造計画および施工計画、建築技術 第 747 号, pp46-53，2012.4

注

注 1) 複数の座標系の点群データを用いる場合、各データのターゲット座標を 元に、同一の座標系への変換を行うが、この際座標変換のズレを最小にす る必要がある。この座標変換については最小二乗法を用いている。異なる 座標系をもつ点群データ同一の座標系に統合する問題は下記のように表現 できる。

主座標系のターゲット群を $\mathrm{R} 2(\mathrm{i}=0,1, \cdots, \mathrm{N})$ 、変換対象のターゲット群を $\mathrm{R} 1(\mathrm{i}=0,1, \cdots, \mathrm{N})$ とする。 $\mathrm{R} 1$ を、回転行列 $R$ を用いて回転し、Tだけ平行移 動した $\mathrm{R} 1$ が $\mathrm{R} 2$ に一致する $R 、 T$ を求める (1)式)。

$$
\mathrm{R} 2=R^{*} \mathrm{R} 1+T(\mathrm{i}=0,1, \cdots, \mathrm{N}) \quad \cdots(1)
$$

この時、各行列は下記のようなる。 


$$
R=\left(\begin{array}{lll}
a_{11} & a_{12} & a_{13} \\
a_{21} & a_{22} & a_{23} \\
a_{31} & a_{32} & a_{33}
\end{array}\right) \quad T=\left(\begin{array}{l}
x_{0} \\
y_{0} \\
z_{0}
\end{array}\right) \quad R_{2}=\left(\begin{array}{l}
x_{2} \\
y_{2} \\
z_{2}
\end{array}\right) \quad R_{1}=\left(\begin{array}{l}
x_{1} \\
y_{1} \\
z_{1}
\end{array}\right)
$$

ゆえに(1)式の右辺は

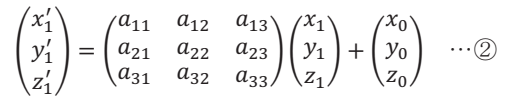

いま、回転行列を、 $\mathrm{x}$ 軸を回転の軸として $\omega 、 \mathrm{y}$ 軸を回転の軸として $\varphi$ $\mathrm{z}$ 軸を回転の軸として うになる。

$R=\left(\begin{array}{lll}a_{11} & a_{12} & a_{13} \\ a_{21} & a_{22} & a_{23} \\ a_{31} & a_{32} & a_{33}\end{array}\right)$

$=\left(\begin{array}{ccc}1 & 0 & 0 \\ 0 & \cos \omega & -\sin \omega \\ 0 & \sin \omega & \cos \omega\end{array}\right)\left(\begin{array}{ccc}\cos \varphi & 0 & \sin \varphi \\ 0 & 1 & 0 \\ -\sin \varphi & 0 & \cos \varphi\end{array}\right)\left(\begin{array}{ccc}\cos \kappa & -\sin \kappa & 0 \\ \sin \kappa & \cos \kappa & 0 \\ 0 & 0 & 1\end{array}\right)$

$\cos \varphi \cos \kappa$

$=\cos \omega \sin \kappa+\sin \omega \sin \varphi \cos \kappa \quad \cos \omega \cos \kappa-\sin \omega \sin \varphi \sin \kappa$

$\sin \omega \cos \varphi$

$\left(\begin{array}{lll}\sin \omega \sin \kappa-\cos \omega \sin \varphi \cos \kappa & \sin \omega \cos \kappa+\cos \omega \sin \varphi \sin \kappa & \cos \omega \cos \varphi\end{array}\right)$

(2)式の左項を $R_{1}^{\prime}=\left(\begin{array}{lll}x_{1}^{\prime} & y_{1}^{\prime} & z_{1}^{\prime}\end{array}\right)^{t}$ とおくと、

$$
D_{i}(A)=\left\|R_{2 i}-R_{1 i}^{\prime}\right\|
$$

以下の式(3)を最小化するような変数群 $\mathrm{A}\left(\omega, \varphi, \kappa, x_{0}, y_{0}, z_{0}\right)$ を探す問題に 帰着する。

$$
D_{i}(A)^{2}=\left\|R_{2 i}-R_{1 i}^{\prime}\right\|^{2}
$$

$$
\sum_{i=0}^{N} D_{i}(A)^{2}=\sum_{i=0}^{\mathrm{N}}\left\|R_{2 i}-R_{1 i}^{\prime}\right\|^{2 \cdots(3)}
$$

(3)式は以下の式を用いると(4)式に書き換え可能である。

$$
\begin{aligned}
& F x_{i}=x_{2}-x_{1}^{\prime} \\
& F y_{i}=y_{2}-y_{1}^{\prime} \\
& F z_{i}=z_{2}-z_{1}^{\prime}
\end{aligned}
$$

$$
\sum_{i=0}^{N}\left(D_{i}(A)\right)^{2}=\sum_{i=0}^{N}\left(F x_{i}^{2}+F y_{i}{ }^{2}+F z_{i}{ }^{2}\right) \cdots \text { (4) }
$$

(4)式が最小值をとるとき、(4)式を変数 $\mathrm{A}\left(\omega, \varphi, \kappa, x_{0}, y_{0}, z_{0}\right)$ についてそれぞ れ偏微分した式の值はゼロになる。つまり

$$
\left\{\begin{array}{c}
\sum_{i=0}^{N} \frac{\partial\left(D_{i}(A)\right)^{2}}{\partial \omega}=2 \sum_{i=0}^{\mathrm{N}}\left(F x_{i} \frac{\partial F x_{i}}{\partial \omega}+F y_{i} \frac{\partial F y_{i}}{\partial \omega}+F z_{i} \frac{\partial F z_{i}}{\partial \omega}\right)=0 \\
\sum_{i=0}^{N} \frac{\partial\left(D_{i}(A)\right)^{2}}{\partial \varphi}=2 \sum_{i=0}^{\mathrm{N}}\left(F x_{i} \frac{\partial F x_{i}}{\partial \varphi}+F y_{i} \frac{\partial F y_{i}}{\partial \varphi}+F z_{i} \frac{\partial F z_{i}}{\partial \varphi}\right)=0 \\
\sum_{i=0}^{N} \frac{\partial\left(D_{i}(A)\right)^{2}}{\partial \kappa}=2 \sum_{i=0}^{\mathrm{N}}\left(F x_{i} \frac{\partial F x_{i}}{\partial \kappa}+F y_{i} \frac{\partial F y_{i}}{\partial \kappa}+F z_{i} \frac{\partial F z_{i}}{\partial \kappa}\right)=0 \\
\sum_{i=0}^{\mathrm{N}} \frac{\partial\left(D_{i}(A)\right)^{2}}{\partial x_{0}}=2 \sum_{i=0}^{\mathrm{N}} F x_{i} \frac{\partial F x_{i}}{\partial x_{0}}=0 \\
\sum_{i=0}^{\mathrm{N}} \frac{\partial\left(D_{i}(A)\right)^{2}}{\partial y_{0}}=2 \sum_{i=0}^{\mathrm{N}} F y_{i} \frac{\partial F y_{i}}{\partial y_{0}}=0 \\
\sum_{i=0}^{\mathrm{N}} \frac{\partial\left(D_{i}(A)\right)^{2}}{\partial z_{0} z}=2 \sum_{i=0}^{\mathrm{N}} F z_{i} \frac{\partial F z_{i}}{\partial z_{0}}=0
\end{array}\right.
$$

(5)式を満たすような $\mathrm{A}\left(\omega, \varphi, \kappa, x_{0}, y_{0}, z_{0}\right)$ を求めればよい。(5)式は非線形連 立方程式なので Levenberg-Marquardt 法を用いて、最適解を求める。

（2012年12月10日原稿受理，2013年 2 月22日採用決定） 